University of Nebraska - Lincoln

DigitalCommons@University of Nebraska - Lincoln

\title{
Influence of Agriculture on Aquatic Invertebrate Communities of Temporary Wetlands in the Prairie Pothole Region of North Dakota, USA
}

Ned H. Euliss Jr.

U.S. Geological Survey, ceuliss@usgs.gov

David M. Mushet

U.S. Geological Survey, dmushet@usgs.gov

Follow this and additional works at: https://digitalcommons.unl.edu/usgsnpwrc

Euliss, Ned H. Jr. and Mushet, David M., "Influence of Agriculture on Aquatic Invertebrate Communities of Temporary Wetlands in the Prairie Pothole Region of North Dakota, USA" (1999). USGS Northern Prairie Wildlife Research Center. 264.

https://digitalcommons.unl.edu/usgsnpwrc/264

This Article is brought to you for free and open access by the US Geological Survey at DigitalCommons@University of Nebraska - Lincoln. It has been accepted for inclusion in USGS Northern Prairie Wildlife Research Center by an authorized administrator of DigitalCommons@University of Nebraska - Lincoln. 


\title{
INFLUENCE OF AGRICULTURE ON AQUATIC INVERTEBRATE COMMUNITIES OF TEMPORARY WETLANDS IN THE PRAIRIE POTHOLE REGION OF NORTH DAKOTA, USA
}

\author{
Ned H. Euliss, Jr. and David M. Mushet \\ U.S. Geological Survey \\ Northern Prairie Wildlife Research Center \\ Jamestown, North Dakota, USA 58401
}

\begin{abstract}
We evaluated the influence of intensive agriculture on invertebrate communities of temporary wetlands as indicated by aquatic invertebrate resting eggs, shells, and cases remaining after wetlands dried. To facilitate the comparison, we sampled 19 wetlands within cropland arcas and 19 wetlands within grassland areas. We found resting eggs, shells, and cases of significantly more taxa and greater numbers of cladoceran resting eggs (ephippia), planorbid and physid snail shells, and ostracod shells in wetlands within grasslands than in croplands. We also successfully incubated greater numbers of cladocerans and ostracods from soil samples collected from grassland sites. We were unable to detect differences in the viability of cladoceran ephippia between grassland and cropland wetlands, but our sample size was small due to an absence of ephippia in most cropland wetlands sampled; $74 \%$ of the cropland wetlands were devoid of cladoceran ephippia whereas ephippia were well represented in nearly all of our grassland sites. Our results corroborate findings of other investigators that prairie pothole wetlands have been negatively impacted by human activities. Our study demonstrates that aquatic invertebrates of temporary wetlands have been negatively impacted by intensive agriculture and suggests that future studies need to assess the influence of agricultural practices on wetland-dependant wildlife.
\end{abstract}

Key Words: agricultural impacts, aquatic invertebrates, Branchiopoda, cases, Cladocera, cphippia. Gastropoda. North Dakota, Ostracoda, prairie pothole region, resting eggs, shells, temporary wetlands, Trichoptera

\section{INTRODUCTION}

North Dakota consists of 17.870 million ha of land area, of which 16.269 million ha is currently (1997) divided among 30,500 farms (ND Agricultural Statistics Service 1998a). In 1997, over 11 million ha of North Dakota's farmland were planted to small grains and row crops (ND Agricultural Statistics Service 1998b) requiring extensive manipulation of the soils and applications of agrichemicals. Some of these lands have been in crop production since the late $1800 \mathrm{~s}$ when the region was first opened to homesteading. Wetlands in the prairie pothole region (PPR) of North Dakota have been severely altered by past and current agricultural practices. Dahl (1990) estimates that $49 \%$ of the wetland area originally present in North Dakota has been drained or filled, primarily for the production of agricultural crops. Wetland losses have also been severe in other parts of the PPR as well; Iowa has lost nearly $90 \%$ of its original wetland area while Minnesota and South Dakota have lost $42 \%$ and $35 \%$ respectively (Dahl 1990). Most remaining wetlands are degraded; upland catchment areas are often tilled which increases sedimentation rates (Martin and Hart- man 1986, Gleason and Euliss 1996), chemical drift from adjacent fields enters wetlands (Grue et al. 1989), and water-level fluctuations are more variable than in wetlands within noncultivated landscapes (Euliss and Mushet 1996a). Moreover, wetland drainage has altered natural hydrologic cycles of remaining wetlands, and drainage of temporary and seasonal wetlands into semipermanent wetlands has altered historic water depths and hydroperiods throughout the PPR.

Of the 7 wetland classes identified by Stewart and Kantrud (1971), temporary wetlands are likely the most vulnerable to agriculture. During years of average precipitation, temporary wetlands contain water for very short periods, typically after spring runoff or other precipitation events. Temporary wetlands are often cultivated and typically produce crops during all but the wettest years (Stewart and Kantrud 1973). Thus, temporary wetlands in agricultural fields are frequently cultivated and receive direct applications of herbicides, pesticides, and fertilizers. Examining agricultural impacts on plant communities of wetlands in the PPR, Kantrud and Newton (1996) reported lower plant species diversity and greater percentages of unvegetated bottom in the wet meadow communities of 
agricultural wetlands: the wet meadow zone is the dominant zone of temporary wetlands in the PPR (Stewart and Kantrud 1971). Additionally, Kantrud and Stewart $(1977,1984)$ reported that waterfowl and other wetland birds rarely used intensively tilled wetlands with large areas of unvegetated bottom.

Efforts to assess and monitor condition of aquatic invertebrate communities of wetlands in the PPR have been hampered by high spatial and temporal variability (Euliss and Mushet 1996b). Much of the invertebrate community variability is attributable to the cyclical nature of climate in this region. The PPR routinely goes through periods of drought followed by abundant rainfall, with extremes in climate usually being separated by 10 or more years (Duvick and Blasing 1981, Karl and Koscielny 1982, Diaz 1983, 1986, Karl and Riebsame 1984). In addition to this strong interannual climate cycle, precipitation events can be extremely localized, often with drought and flood conditions occurring simultaneously within short geographic distances, both within and among ecoregions. Wetland biota in the PPR are well-adapted to the naturally dynamic hydrology of the area and are also highly dynamic, both in abundance and community composition. Hence, presence or absence of a particular species at a certain time may not reflect general wetland condition.

Branchiopoda, including water fleas (Cladocera), fairy shrimp (Anostraca), clam shrimp (Conchostraca), and tadpole shrimp (Notostraca), are wide-spread residents of freshwater habitats (Hutchinson 1967), and they produce drought-resistant resting eggs. Resting eggs present in wetland sediments are the faunal equivalent of hydrophytic seed banks (hereafter referred to as "egg banks"). Like seed banks, egg banks remain viable in dried soils for extended periods, possibly decades (Pennak 1989). Other invertebrates of temporary wetlands leave behind evidence of their existence in the form of shells and cases after a wetland dries. Snails, ostracods, and conchostracans have decay-resistant shells that remain in the soils of temporary wetlands after they dry in the summer. Trichopterans construct cases that are an easily identified indicator of their past presence long after the case build er is gone.

We evaluated an invertebrate sampling approach that is less affected by the natural variability of freeliving invertebrates in an effort to develop techniques to monitor wetland condition for the U.S. Environmental Protection Agency's (EPA) Environmental Monitoring and Assessment Program (EMAP). As wetlands pass through drought cycles, invertebrate communities respond to changes in hydrology and chemistry. During severe drought, wetlands dry out completely. Upon reflooding, invertebrates recolonize

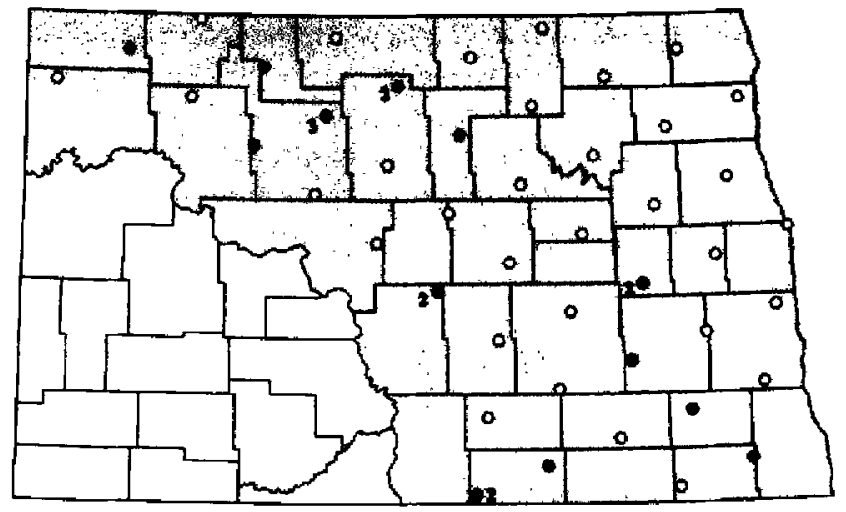

Figure 1. The prairie pothole region of North Dakota showing locations of EMAP hexagons and wetland pairs sampled. Solid hexagons contained the paired wetland sites sampled in this study. Numbers next to hexagons indicate number of wetland pairs in hexagons with more than one pair.

these wetlands using a variety of means, including resting eggs and cysts, diapause, and aestivation (Wiggens et al. 1980, Euliss et al. 1999). Resting eggs, cysts, and nonactive invertebrates remaining in wetland sediments, plus the decay-resistant shells and cases left from previous cohorts provide an integrated signature of the invertebrate community over time. They also provide a reflection of potential invertebrate community structure when wetlands reflood. Dry soil from wetland sediments contains invertebrate eggs, decayresistant shells, and other body parts that can provide a historical measure of the invertebrate community of a wetland. Long-term impacts of land use on aquatic invertebrates are reflected in these invertebrate signatures.

The primary goal of our study was to determine if taxon richness and abundance of invertebrate resting eggs, shells, and cases remaining in the soils of temporary wetlands were reduced by agricultural activity. Additionally, we compared viability of cladoceran resting eggs collected from temporary wetlands within agricultural and grassland dominated watersheds to assess impacts of intensive agriculture on population viability.

\section{METHODS}

\section{Field Methods}

We collected soil samples from 19 wetland pairs located throughout the PPR of North Dakota (Figure 1) during a single visit to cach sitc: we sampled 14 wetland pairs during the summer of 1995 and an additional 5 pairs during the summer of 1996. Wetland pairs were identified from $40 \mathrm{~km}^{2}$ hexagons that were established by the EPA to monitor wetland condition 
for EMAP. Each wetland pair consisted of a randomly selected temporary wetland and the closest temporary wetland of the opposite condition class. The condition classes we identified for this study were 1) temporary wetlands with catchment basins (i.e., area immediately surrounding each wetland from which surface water flows into the basin) within intensively farmed agricultural fields (hereafter referred to as "cropland wetlands") and 2) temporary wetlands with catchment basins entirely within U.S. Fish and Wildlife Service Waterfowl Production Areas or similar grassland habitat (hereafter referted to as "grassland wetlands"). The spatial location and classification of each wetland was verified when basins were flooded in early spring from snow melt.

From each study wetland, we collected ten $500-\mathrm{ml}$ soil samples. First, we located the lowest elevation of the basin using a Spectra-Physics Model 650 Laserplane. Here, we established a $2 \times 2$ m quadrat comprised of a $20 \times 20$ grid of four hundred $100-\mathrm{cm}^{2}$ cells. We collected one $250-\mathrm{ml}$ sample of soil from each of 20 randomly selected cells within the quadrat. Samples were taken from the top $5 \mathrm{~cm}$ of soil using a hand trowel after loose vegetative litter was removed from the soil surface by hand. All soil samples from a single wetland were combined in a large, plastic mixing bowl and homogenized using a hand trowel. Homogenized samples were subdivided into ten $500-\mathrm{ml}$ subsamples, placed in polypropylene jars, frozen, and stored at $0^{\circ} \mathrm{C}$ until processed.

\section{Laboratory Methods}

We sorted 5 of the 10 soil samples collected from each wetland by hand to estimate the abundance of cladoceran resting eggs (ephippia) and other invertebrate remains. Soil samples were thawed for 24 hours before processing. We then passed samples through a $0.5-\mathrm{mm}$ standard soil sieve and rinsed them with water to remove small soil particles and other material; residues larger than $0.5 \mathrm{~mm}$ (e.g., ephippia, snail shells. ostracod shells) were retained on sieve screens. Residues were then placed in a $23 \times 36 \times 5 \mathrm{~cm}$ Pyrex baking dish, covered with $1-2 \mathrm{~cm}$ of water, and examined on a light table. We sorted all residues and transferred ephippia and all other invertebrate remains to petri dishes; every fifth sample was reexamined to verify completeness of sorts. Ephippia and other invertebrate remains were identified, enumerated, and recorded.

To cstimate relative abundance of small invertebrate eggs that were easily missed by hand-sorting (i.e., those of anostracans, conchostracans, notostracans, and ostracods), the remaining 5 soil samples from each wetland were incubated for 8 weeks in $37.8-\mathrm{L}$ glass aquaria filled with water maintained under standardized conditions of light, temperature, and water chemistry described below. Many authors have shown that light, temperature, oxygen, and osmotic conditions are the most important factors influencing diapause release and development of resting eggs (e.g. Ogi et al. 1951, Panchella and Stross 1963, Proctor 1964, Stross and Hill 1965, Stross 1966, Shan 1970). Resting eggs collected from the field during dry conditions have usually been exposed to dynamic fluctuations in temperature and moisture and will hatch under optimal water and chemistry regimes (Moritz 1987).

Before samples were placed in aquaria, specific conductance of the water was adjusted to $700 \mu \mathrm{S} \mathrm{cm}^{-1}$ by diluting well water with distilled water. We illuminated each aquarium using a full-spectrum flourescent tube set on a timer to provide $12 \mathrm{hr}$ of light each day. Water temperatures were maintained at $10^{\circ} \mathrm{C}$ for the initial 28 days of the incubations and then increased and maintained at $20^{\circ} \mathrm{C}$ for an additional 28 days to simulate carly spring and late summer thermal regimes. After hatching, invertebrates were counted and removed as soon as accurate identifications could be made. All invertebrates were removed before they reproduced.

\section{Statistical Methods}

We used analysis of variance (ANOVA) techniques to assess effects of wetland condition class (grassland or cropland) on the number and viability of cladoceran ephippia and the number and taxon richness of other invertebrate eggs and remains in soil of the temporary wetlands. We conducted the ANOVAs using the general linear modets procedure (PROC GLM) of SAS (SAS Institute, Inc. 1989) with a randomized block design; each wetland pair represented a block. Counts from individual samples were summed for each wetland prior to analysis. We calculated viability of cladoceran ephippia as the ratio of the number of cladocerans successfully incubated in aquaria to the number of ephippia found by hand-sorting. We transformed all data, except taxon richness, to stabilize variance (Steel and Torrie 1980); a square root transformation was used on the viability data, and remaining variables were converted to their natural logs. Here, we report back-transformed means and confidence intervals. Due to a lack of cladoceran ephippia in most cropped wetlands (only 5 of 19 contained ephippia), we restricted analysis of our viability data to the 5 wetland pairs that had paired values for both grassland and cropland wetlands. More precise estimates of viability resulted when more ephippia were present (i.e., 75 of 100 ephippia hatching was a better estimate that $75 \%$ of the ephippia in a wetland were viable than if 3 of only 


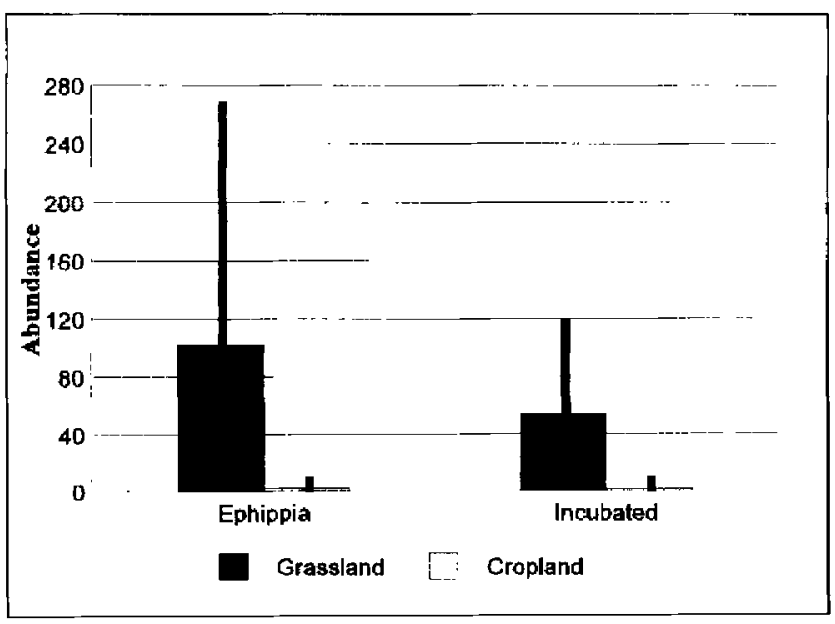

Figure 2. Back-transformed mean abundances and 95\% confidence intervals of Cladocera resting eggs (ephippia) and individuals found in and incubaled out of soil samples collected from wetlands within grassland and cropland watersheds. All differences observed were significant $(p<$ 0.05 ).

4 hatched); thus, in our ANOVAs, we weighted our viability estimates by the number of ephippia found by hand-sorting to give more weight to the better estimates.

\section{RESULTS}

We identified resting eggs and remains of 6 invertebrate taxa in our hand-sorted soil samples (i.e., cladoceran ephippia, planorbid snail shells. lymnaeid snail shells, physid snail shells, ostracod shells, and trichopteran cases). Number of invertebrate taxa in soil samples differed $\left(\mathrm{F}_{1,1 \mathrm{x}}=14.00, p=0.0015\right)$ between grassland $(\overline{\mathrm{x}}=2.947, \mathrm{SE}=0.388)$ and cropland $(\overline{\mathrm{x}}=$ $0.895, \mathrm{SE}=0.388$ ) wetlands. We found more cladoceran ephippia in soil samples from grassland wetlands than in samples collected from cropland wellands $\left(F_{1.15}\right.$ $=27.45, p<0.0001$ ) (Figure 2). In fact, ephippia were entirely absent from the soils of 14 of the 19 cropland wetlands. All 19 grassland wetlands except one contained cladoceran ephippia. Both planorbid snail shells and physid snail shells occurred in greater numbers $\left(\mathrm{F}_{1.1 \%}=13.31, p=0.0018\right.$ and $\mathrm{F}_{1,1 \mathrm{k}}=6.93, p=$ 0.0169 , respectively) in soil samples from grassland wetlands than in those from cropland wetlands (Figure 3). We also found greater numbers of ostracod shells in samples from grassland versus cropland wetlands $\left\langle\mathbf{F}_{1.1 \mathrm{k}}=4.71, p=0.0436\right)$. Although there appeared to be more lymnaeid snail shells in samples collected from wetlands in grassland, we were unable to separate the two condition classes $\left(\mathrm{F}_{1 . \mathrm{I} K}=1.23, p=0.2823\right)$. Number of trichopteran cases also did not differ $\left(\mathrm{F}_{1, \mathrm{ik}}\right.$ $=0.01, p=0.9051$ ) among the condition classes, but

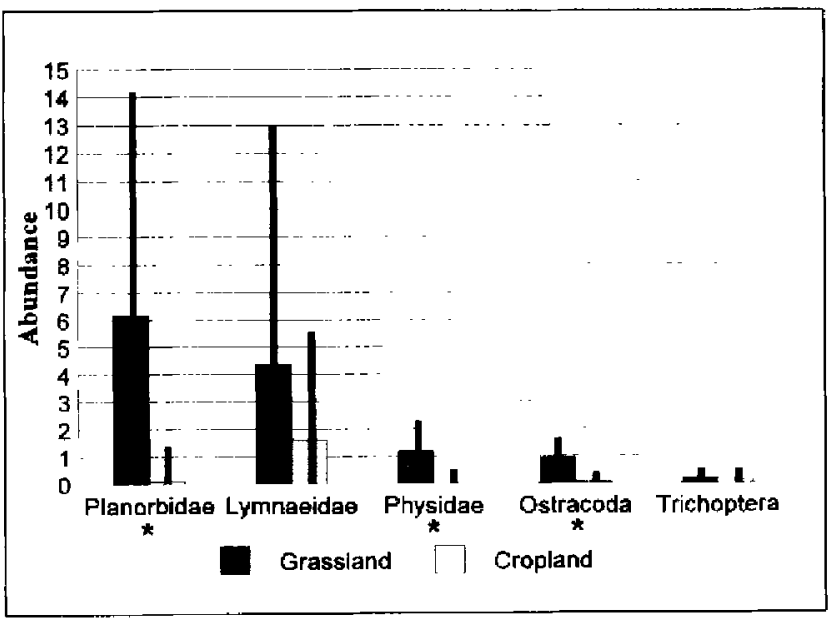

Figure 3. Back-transformed mean abundances and $95 \%$ confidence intervals of planorbid snail, lymnaeid snail, physid snail, and ostracod shells and trichopteran cases found in soil samples from wetlands within grassland and cropland watersheds. An $*$ indicates that differences were significant $(p<0.05)$.

these occurred only rarely in our study wetlands (Figure 3 ).

Cladocerans, anostracans, and ostracods were the only invertebrates successfully incubated in our aquaria. However, we found more invertebrate taxa in our incubated soil samples from grassland wetlands $\left(\mathrm{F}_{1,1 \mathrm{x}}\right.$ $=19.00, p=0.0004)$ than in soil samples from crop land wetlands $(\bar{x}=1.632, S E=0.162$ versus $\bar{x}=$ $0.632, \mathrm{SE}=0.162$ ). Number of cladocerans incubated from soil samples also reflected differences we observed in hand-sorted samples (Figure 2) with greater numbers incubated from the grassland samples $\left(\mathrm{F}_{1,18}=\right.$ 28.67, $p<0.0001)$. Number of incubated anostracans (Figure 4) did not differ between wetland condition classes $\left(F_{1,3 k}=1.21, p=0.2855\right)$; however like trichopteran cases in our hand-sorting analysis, anostracans were rare and were incubated from only 4 wetland samples. Reflecting the trend observed in our hand-sorting data, incubated ostracod numbers differed by condition class $\left(\mathrm{F}_{1.18}=4.69, p=0.0440\right)$, with greater numbers being incubated from the grassland samples (Figure 4).

We were unable to detect any differences in viability of cladoceran ephippia $\left(\mathrm{F}_{1,4}=0.23, p=0.6578\right)$ among grassland (back-transformed mean $=0.380$ ) and cropland (back-transformed mean $=0.498$ ) wetlands; however, our sample was restricted to only those 5 wetland pairs that contained ephippia in both condition categories. Extreme variability and wide confidence intervals $(-0.023$ to 0.905 and -0.012 to 1.189 , respectively) could have easily obscured any differences that may have existed. 


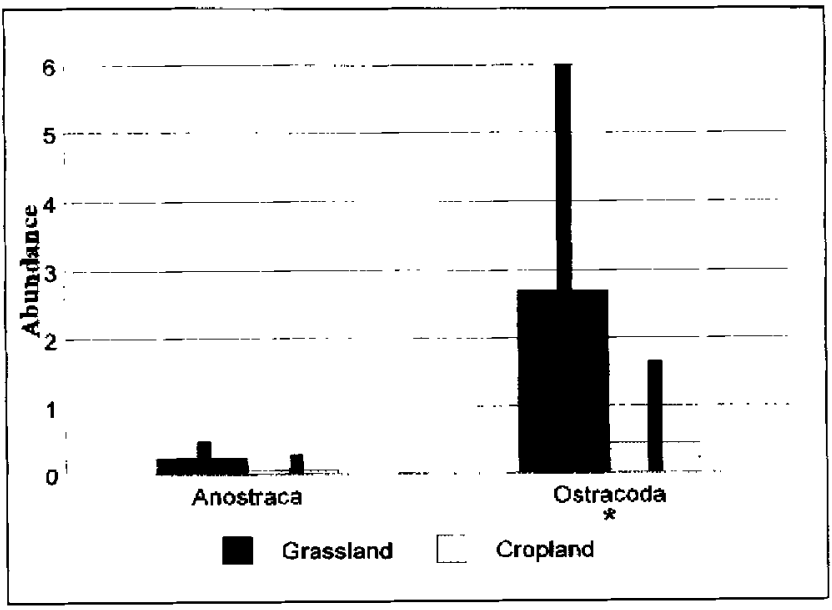

Figure 4. Back-transformed mean abundances and 95\% confidence intervals of fairy shrimp (Anostraca) and seed shrimp (Ostracoda) incubated from soil samples collected from wetlands within grassland and cropland watershods. An * indicates that differences were significant $(p<0.05)$.

\section{DISCUSSION}

Our study clearly suggests that current agricultural practices have had major negative impacts on aquatic invertebrate communities of temporary wetlands in the PPR of North Dakota. Several practices associated with modern agriculture may have impacted invertebrate egg banks by lowering numbers of ephippia and other invertebrate eggs; the remains of snails and ostracods were also reduced in cropland wetlands. Agrichemicals have been demonstrated to cause significant increases in aquatic invertebrate mortality (Borthwick 1988, Grue et al. 1989). Additionally, the physical effects of cultivation, such as increased erosion and sedimentation, probably reduced invertebrates in cropland wetlands. Suspended silt and clay can be toxic to zooplankton and reduce foraging and food assimilation rates of aquatic invertebrates (Robinson 1957. McCabe and O'Brien 1983. Newcombe and MacDonald 1991). Increased suspended sediments also clog filtering apparatuses of invertebrates and may reconfigure aquatic food webs by shading primary producers (Gleason and Euliss 1996). Sedimentation buries seed banks in wetlands (Jurik et al. 1994, Wang et al. 1994) and presumably invertebrate egg banks (Euliss et al. 1999). Tillage of uplands surrounding wetland basins increases water-level fluctuations and probably impacts invertebrate communities through altered water chemistry and hydroperiod (Euliss and Mushet 1996a).

Agricultural practices may also have less obvious impacts on invertebrate communities in wetlands. Wetland drainage in the PPR has been focused primarily on shallow temporary and seasonal wetlands within agricultural fields. This increases the distance between wetlands, thereby increasing the distances aquatic invertebrates must travel to repopulate wetlands. Hence, repopulation following natural drought cycles may be prevented or delayed (Euliss et al. 1999). Dispersal by wind (Pennak 1989), in the digestive tracts of birds (Proctor 1964, Proctor et al. 1967, Swanson 1984), and by clinging to vertebrate and invertebrate fauna (Segersträle 1954, Rosine 1956, Fryer 1974, Peck 1975, Swanson 1984) may also be diminished if the distance between remaining wetlands is increased.

Temporary wetlands dry quickly during most years, and most farming operations cultivate their basins and adjacent upland areas. Kantrud and Newton (1996) found lower plant species diversity and greater percentages of unvegetated bottom in the wet meadow zones of agricultural wetiands, and Kantrud and Stewart $(1977,1984)$ found poor bird use of tilled prairic wetlands. Our rexults suggest that agricultural practices have limited invertebrate communities as well. Of all the wetland classes in the PPR, temporary wetlands are most directly influenced by farm operations; hence, their condition may provide a general indication of wetland health within an area. In much the same fashion as "indicator species" in biological assemblages, temporary wetlands may alert managers of potential problems in an area that may include more permanent wetland classes. Future work should address the relationship between the condition of temporary wetlands and the condition of other habitats in an area, including more permanent wetlands.

Our study demonstrates that aquatic invertebrate communities of temporary wetlands in the PPR have been altered by agriculture. Future studies are needed to clarify causal mechanisms and the ecological implications on other wetland-dependent communities, such as waterfowl that utilize these wetlands to satisfy nutritional requirements (Swanson et al. 1977). We suggest that future studies be initiated collaboratively with agricultural interests to facilitate development of interdisciplinary approaches that promote land management practices beneficial to both wildlife and agricultural interests (Gleason and Euliss 1998).

\section{ACKNOWLEDGMENTS}

We thank J. A. Austin, M. A. Hanson, and S. A. Peterson for review of this manuscript and D. A. Buhl for conducting the statistical analyses. This research was sponsored by the U.S. Environmental Protection Agency. Use of brand names in this manuscript does not constitute nor imply endorsement by the U.S. Government. 


\section{LITERATURE CITED}

Borthwick, S. M. 1988. Impacts of agricultural pesticides on aquatic invertehrates inhabiting prairie wetlands. M.S. Thesis. Colorado State University, Fort Collins, CO, USA.

Dahl, T. E. 1990. Wetland losses in the United States 1780's to $1980^{\circ}$ s. U. S. Fish and Wildlife Service. Washington, DC. USA.

Diaz, H. F. 1983. Some aspects of major dry and wet periods in the contiguous United States, 1895-1981. Journal of Climate and Applicul Meteorology 22:3-16.

Diaz, H. F. 1986. An analysis of twentieth century climate fluctuations in torthern North America. Journal of Climate and Applied Meteorology 25:1625-1657.

Duvick. D. N. and T. J. Blasing. 1981. A dendroclimatic reconstruction of annual precipitation amounts in lowa since 1680 . Water Resource Rescarch 17:1183-1189.

Euliss. N. H.. Jr. and D. M. Mushet. 1996a Water-level fluctuations in wetlands as a function of landscape condition in the prairie pothole region, Wetlands 16:587-593.

Euliss, N. H., Jr. and D. M. Mushet. 1996b. Impacts of agricultural practices on wetland macroinvertebrates, siltation rates, and waterlevel fluctuations. p. 59-69. In S. A. Peterson, L. Carpenter, G. Guntenspergen, and L. M. Cowardin (eds.), Pilot test of wetland condition indicators in the prairie pothole region of the United States. L.S. Environmental Prolection Agency. Washinglon, DC. USA. EPA/620/R-97-002.

Euliss, N. H.. Jr.. D. A. Wrubleski, and D. M. Mushet. 1999. Invertebrates in wetlands of the prairie pothole region: species compusition. ecology, and management p. 471-513, In D. P. Batcer R. B. Rader, and S. A. Wissinger (eds.) Invertebrates in Freshwater Wetlands of North America: Ecology and Management. John Wiley \& Sons, New York. NY, USA.

Fryer, G. 1974. Attachment of bivalve molluses to corixid bugs. Naturalist 928: 18

Gleason, R. A. and N. H. Euliss. Jr. 1996. Sedimentation of prairie pothole wetlands: the need for integrated research by agricultural and wildlife interests. Proceedings of the 1996 wetlinds seminar. Water for agriculture and wildlife and the cnvironment-win-win opportunities. U. S. Committee on Irrigation and Drainage, Denver. CO, USA.

Gleason. R. A. and N. H. Euliss. Jr. 1998. Sedimentation of prairie wotlands. Groat Plains Research 8:97-112.

Grue. C. E.. M. W. Tome, T. A. Messmer, D. B. Henry, G. A. Swanson. and L. R. DeWeese. 1989. Agricultural chemicals and prairie pothole wetlands: mecting the needs of the resource und the farmer-U. S. perspective. Transactions of the North American Wildlife and Natural Resources Conference 54:43-58

Hutchinson. G. E. 1967. A Treatise on Limnology. Vol, 2: Introduction to Lake Biology and the Limnoplankton. John Wiley and Sons. New York, NY, USA

Jurik. T. W. S. C. Wang. and A. G. van der Valk. 1994. Effects of sediment load on seedling emergence from wetland seed banks. Wetlands 14:159-165.

Kantrud, H. A. and W. E. Newton. 1996. A test of vegetation-related indicators of wetland quality in the prairie pothole region. Journal of Aquatic Ecosystem Health 5: 177-191.

Kantrud. H. A. and R. E. Stewart. 1977. Lse of natural basin wet lands by breeding waterfowl in North Dakota. Journal of Wildlife Management 41:243-253.

Kantrud. H. A. and R. E. Stewant. 1984. Ecological distribution and crude density of breeding birds on prairie wetlands. Journal of Wildlife Management 48:426-437.

Karl. T. R. and A. J. Koscielny. 1982. Drought in the United States: 1895-1981. Iournal of Climatology 2:313-329.

Karl. T. R. and W. E. Riebsame. 1984. The identification of 10 to 20 year temperature and precipitation fluctuations in the contiguous United States. Journal of Climate and Applied Meteorology 23:950-966

Martin, D. B. and W. A. Hartman. 1986. The effect of cultivation on sediment and deposition in prairje pothole wetlands. Water, Air. and Soil Pollution 34:45-53.

McCabe. G. D. and W. J. O'Brien. 1983. The effects of suspended silt on feeding and reproduction of Daphnia pulex. American Midland Naturalist 1 10:324-337.

Mority. C. 1987. A note on the hatching and viability of Ceriodaphnia ephippia collected from lake sediment. Hydrobiologia 145: $309-314$

Newcombe, C. P. and D. D. MacDonald. 1991. Effects of suspended sediments on aquatic ecosystems. North American Journal of Fisheries Management 11:72-82.

ND Agricultural Statistics Service. 1998a. Number of Farms \& Land in Farms. North Dakota Agricultural Statistics Service Home Page. http:/www.nass.usda.gov/nd/ab67009.htm. (Version 18Aug98).

ND Agricultural Statistics Service. J 998 b. North Dakota Crop Sum. mary, 1997: the season in review. North Dakota Agricultural Statistics Service Home Page. http://www.nass.usda.gov/nd/ ab67022.htm. (Version 18Aug98).

Ogi. K., T. Asai, and H. Nakai. 1951. Faetors influencing the start of development in Daphnia pulex winter eggs. Ecological Review $13: 24-26$.

Panchella. J. R. and R. G. Stross. 1963. Light induced hatching of Daphnia resting eggs. Chesapeake Science 4:135-140.

Peck, S. B. 1975. Amphipod dispersal in the fur of aquatic mammals. The Canadian Field-Naturalist 89:181-182

Pennak, R. W. 1989. Fresh-water Invertebrates of the United States. 3rd Edition. John Wiley \& Sorls. New York, NY. LSA.

Proctor, V. W. 1964. Viability of crustacean eggs recovered from ducks. Ficology 45:656-65x.

Proctor, V. W., C. R. Malone. and V. L. DeVlaming. 1967. Dispersal of acuatic organisms: viability ol disseminules recovered from the intestinal traet of captive killdeer. Ecology 48:672-676.

Robinson. M. 1957. The effects of suspended materials on the reproductive rate of Daphnia magna. Publications of the Institute of Marine Science. University of Texas, Port Arkansas, TX 4:265277.

Rosine, w. 1956. On the transport of the common amphipod. $H y$ alella aderte, in South Dakota by the mallard duck. ''rocedings of the South Dakota Academy of Science 35:203.

SAS Institule Inc. 1989. SAS/STAT User's Guide. Version 6. th Edition, Volume 2. SAS Institute Inc.. Cary. NC. CSA.

Segersträle, S. G. 1954. The freshwater amphipods, Gammarus pulex (L.) and Gumplarus tatustris G. O. Sars, Denmark and Fennoscandia-a contribution to the late- and post-glacial immigrition history of the aquatic fauna of northern Europe. Commentatiowes Biologicae Societas Scientiarum Fennica 15:1-9|.

Shan. R. K. 1970. Influence of light on hatching resting eggs of chydorids (Cladocera). Internationate Revue der Gesumten Hydrobiologie 55:295 302

Steel. R. G. D. and J. H. Torrie 1980. Principles and Procedures of Statistics: A Biometrical Approach. Second Editisn. McGraw-Hill Book Co. New York, NY, LISA.

Stewart. R. F. and H. A. Kantrud. 1971. Classitication of natural ponds and lakes in the glaciated prairive region. II S. Fish and Wildlife Service Professional Paper 585-T)

Stewart. R. E. and H. A. Kantrud. 1973. Ecological distribution of breeding waterfowl populations in North Dakota. Journal of Witdlife Management 37:39-50.

Stross, R. G. 1966. Light and temperature requirements for diariause development and relcase in Daphnia. Ecology 47:368-374.

Stross, R. G. and J. C. H Iill. 1965. Diapause induction in Iniphria requires two stimuli. Science 150:1462-l +464 .

Swanson. G. A. 1984. Dissemination of amphipods by waterfowl. Journal of Wildlife Management 48:987-991.

Swanson, G. A., G. L. Krapu, and J. R. Serie. 1977. Foods of linying fentale dabbling ducks on the breeding grounds. p. $47-57 \mathrm{ln}$ T. A. Bonkhout red.I. Waterfowl and Wetlands-in Integrated Review. Proceedings of the 1977 Symposium at the North Central Section. The Wildlife Society, Madison, WI, USA.

Wang $S, C$. T. W. Jurik, and A. G. van der Valk. 1994. liffects of sediment load on various stages in the life and death of cattail $($ Typha $\times$ glauca). Wetlands $] 4: 166-173$

Wiggins, G. B.. R. J. Mackay, and [. M. Smith. 1980. Evolutionary and ecological strategies of inimals in annual temporary pook. Archiv fuer Hydrobiologie Supplement 58:97 206 .

Manuscript receiyed 1 February 1999; accepted 22 April 1999. 